\title{
Geographical distribution of American cutaneous leishmaniasis and its phlebotomine vectors (Diptera: Psychodidae) in the state of São Paulo, Brazil
}

\author{
Paloma Helena Fernandes Shimabukuro ${ }^{1 *}$, Túllio Romão Ribeiro da Silva ${ }^{2}$, Frederico Octávio Ribeiro Fonseca ${ }^{3}$, \\ Luke Anthony Baton ${ }^{4}$, Eunice Aparecida Bianchi Galati ${ }^{5}$
}

\begin{abstract}
Background: American cutaneous leishmaniasis (ACL) is a re-emerging disease in the state of São Paulo, Brazil. It is important to understand both the vector and disease distribution to help design control strategies. As an initial step in applying geographic information systems (GIS) and remote sensing (RS) tools to map disease-risk, the objectives of the present work were to: (i) produce a single database of species distributions of the sand fly vectors in the state of São Paulo, (ii) create combined distributional maps of both the incidence of $A C L$ and its sand fly vectors, and (iii) thereby provide individual municipalities with a source of reference material for work carried out in their area.
\end{abstract}

Results: A database containing 910 individual records of sand fly occurrence in the state of São Paulo, from 37 different sources, was compiled. These records date from between 1943 to 2009, and describe the presence of at least one of the six incriminated or suspected sand fly vector species in 183/645 (28.4\%) municipalities. For the remaining $462(71.6 \%)$ municipalities, we were unable to locate records of any of the six incriminated or suspected sand fly vector species (Nyssomyia intermedia, N. neivai, N. whitmani, Pintomyia fischeri, P. pessoai and Migonemyia migonei). The distribution of each of the six incriminated or suspected vector species of $A C L$ in the state of São Paulo were individually mapped and overlaid on the incidence of ACL for the period 1993 to 1995 and 1998 to 2007. Overall, the maps reveal that the six sand fly vector species analyzed have unique and heterogeneous, although often overlapping, distributions. Several sand fly species - Nyssomyia intermedia and N. neivai - are highly localized, while the other sand fly species - N. whitmani, M. migonei, P. fischeri and P. pessoai - are much more broadly distributed. ACL has been reported in 160/183 (87.4\%) of the municipalities with records for at least one of the six incriminated or suspected sand fly vector species, while there are no records of any of these sand fly species in 318/478 (66.5\%) municipalities with ACL.

Conclusions: The maps produced in this work provide basic data on the distribution of the six incriminated or suspected sand fly vectors of ACL in the state of São Paulo, and highlight the complex and geographically heterogeneous pattern of $\mathrm{ACL}$ transmission in the region. Further studies are required to clarify the role of each of the six suspected sand fly vector species in different regions of the state of São Paulo, especially in the majority of municipalities where $A C L$ is present but sand fly vectors have not yet been identified.

\section{Background}

Phlebotomine sand flies are dipteran insects and some species are vectors of Leishmania spp., the causative agents of American cutaneous leishmaniasis (ACL). The disease has been known to occur in the state of São

\footnotetext{
* Correspondence: phfs@yahoo.com

'Instituto Leônidas e Maria Deane, FIOCRUZ - Amazônia, Rua Terezina, 476,

Adrianópolis, Manaus, Amazonas, Brazil

Full list of author information is available at the end of the article
}

Paulo at least since 1884 [1]. American cutaneous leishmaniasis transmission in São Paulo state initially increased as a consequence of deforestation during the expansion of coffee plantations in the $19^{\text {th }}$ century, and then continued, in the first decades of the $20^{\text {th }}$ century, as coffee farms became widespread towards the northwestern area of the state and railway roads were built to transport coffee grains to the coast [1]. After declining in incidence by the end of the 1950's, ACL became

\section{Biomed Central}

(c) 2010 Shimabukuro et al; licensee BioMed Central Ltd. This is an Open Access article distributed under the terms of the Creative Commons Attribution License (http://creativecommons.org/licenses/by/2.0), which permits unrestricted use, distribution, and reproduction in any medium, provided the original work is properly cited. 
endemic in southern areas of the state in the 1970's [1]. In the 1980's, ACL was considered a re-emergent disease due to anthropic factors and was not directly related to forested environments, as it had been historically [2]. This represented a new feature of transmission, marked by micro-outbreaks or isolated cases scattered throughout the state in rural or peri-urban areas $[2,3]$. Transmission of the Leishmania spp. causing ACL in these areas depends on the adaptation of potential vectors species to anthropic environments and involves domestic animals [4,5].

In the state of São Paulo, the main etiological agent of ACL is Leishmania (Viannia) braziliensis [6]. Five sand fly species are incriminated vectors of $L$. (V.) braziliensis: Nyssomyia intermedia, Nyssomyia neivai, Nyssomyia whitmani, Migonemyia migonei and Pintomyia pessoai $[2,7,8]$; while one other species is a suspected vector: Pintomyia fischeri [2]. Leishmania (Leishmania) forattinii [9] and Leishmania (Leishmania) amazonensis [6] have also been isolated from wild reservoirs, and a small number of human ACL cases caused by L. (L.) amazonensis have been reported in the north-eastern region of São Paulo State [10]. However, the only known vector of $L$. (L.) amazonensis, the sand fly Bichromomyia flaviscutellata, has only been recorded in a restricted area of the south coast of São Paulo state [11,12].

The complexity of ACL transmission is due to the different possible clinical outcomes (cutaneous, mucosal or diffuse) [4], the diversity of sand fly vector species and the diversity of Leishmania species; it is known that different sand fly species can transmit the same or a different Leishmania species [13]. Because vector populations are affected by humidity, temperature, vegetation, light availability and altitude $[14,15]$, it is frequently not possible to identify the vector species in a transmission area. Also, in Brazil, it is common for the health services to report the disease based on histopathological diagnosis accompanied by Montenegro skin test. Parasite characterization is rare, so information on which Leishmania species is causing the disease in most areas of Brazil is unknown.

There has been a significant increase in the use of geoprocessing techniques to understand the transmission of infectious diseases. These techniques allow the analysis of data over large territorial scales and the production of disease maps, ecological analyses, prediction of parasite occurrence and surveillance for various parasitic, including arthropod-borne, diseases [16,17]. Regarding leishmaniasis, geographic information systems (GIS) and remote sensing (RS) techniques have been used to: (i) map disease occurrence, and (ii) build predictive models [18]. With respect to phlebotomine sand flies in the state of São Paulo, GIS/RS techniques have been used for ecological niche modelling of vector species of ACL $[18,19]$, and to map disease and/or vector occurrence $[2,20]$. However, this previous work used data on vector distribution or disease occurrence from limited time periods.

In the present work, we gathered data on the distribution of sand flies in the state of São Paulo during the past 65 years (the period from 1943 to 2009), and compared this data to the distribution of notified ACL cases during the periods from 1993 to 1995 and 1998 to 2007. The aims of the present work were to: (i) collect and then organize the distribution records for sand fly species in the state of São Paulo into a single database, (ii) produce distributional maps of the phlebotomine vectors of ACL and superimpose these data with ACL disease records for the past 15 years, and (iii) thereby provide individual municipalities with a source of reference material for work carried out in their area.

\section{Results}

In order to create maps comparing the distributions of ACL and the six incriminated or suspected sand fly vectors of $L$. ( $V$. .) braziliensis, a single database was constructed combining data on the incidence of ACL and the occurrence of the six different sand fly species investigated, for each of the 645 municipalities of the state of São Paulo (the database is available on request from PHFS). Data on ACL was obtained from the National Database on Reportable Diseases/Epidemiological Surveillance Centre (SINAN/CVE) website [21], while information on the distribution of sand flies was collated from four different sources (as described in detail in the Materials and Methods).

Overall, our database currently contains 910 individual records, from 37 different sources, reporting the occurrence of sand flies in the state of São Paulo (Figure 1). These records date from between 1943 to 2009, and describe the presence of at least one of the six incriminated or suspected sand fly vector species in $183 / 645$ (28.4\%) municipalities, only 23 of which have no records of ACL (Figures 2, 3, 4, 5, 6 and 7). For the remaining $462(71.6 \%)$ municipalities, we were unable to locate records of any of the six incriminated or suspected sand fly vector species. In these latter municipalities, these sand fly species have either been sought but not observed, or appropriate field collections have not been undertaken/publically reported. ACL has been reported in 318/462 (68.8\%) municipalities for which there are no records of the occurrence of any of the six incriminated or suspected sand fly vector species. Most of these municipalities are located in the central and northern regions of the state. In contrast, cases of ACL have been reported in most of the municipalities (160/183; 87.4\%) with records of the occurrence of at least one of the six incriminated or suspected sand fly vector species (Table 1). 


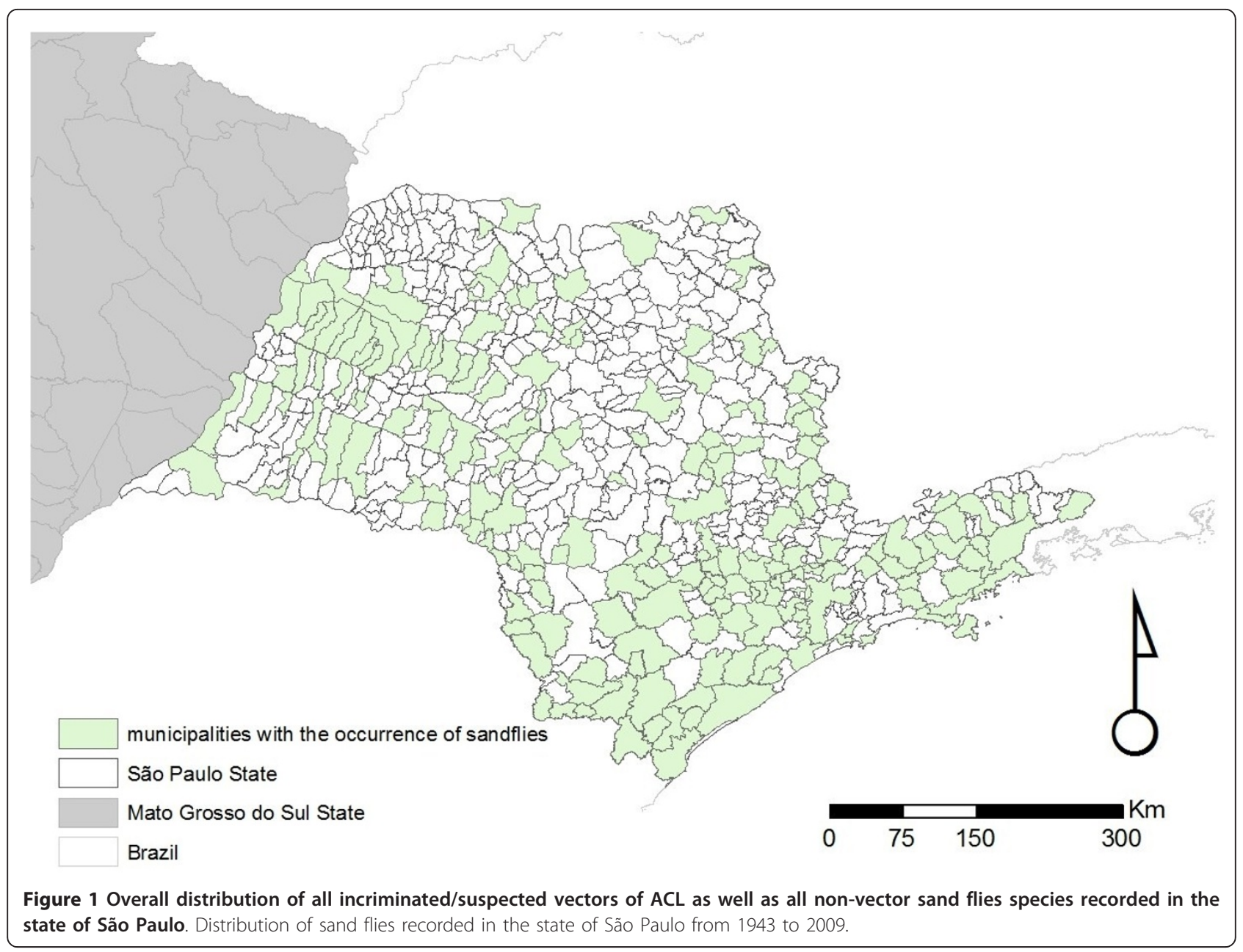

Figures 2, 3, 4, 5, 6 and 7 show separately the distribution of each of the six incriminated or suspected vector species of ACL in the state of São Paulo, overlaid on the incidence of ACL for the period of 1993 to 1995 and 1998 to 2007. The total number of reported cases of ACL in the state of São Paulo between 1998 and 2007 was 6,643 [21]. During this period, ACL was reported in 478/645 (74.1\%) municipalities (Figures 2, 3, 4, 5, 6 and 7). Although there is a widespread, low level of endemic ACL distributed throughout the entire state of São Paulo, there are also several highly localized areas with a relatively high incidence of ACL (Figures 2, 3, 4, 5, 6 and 7 ). These regions are primarily (i) the southernmost and south-eastern coastal regions of the state, which consist of the protected Atlantic forest areas, and (ii) the city of São Paulo and its associated surrounding conurbation (Figures 2, 3, 4, 5, 6 and 7).

In contrast to the widespread occurrence of ACL throughout the state of São Paulo, the incriminated or suspected sand fly vector species have more circumscribed and heterogeneous distributions (Figures 2, 3, 4,
5, 6 and 7). Several sand fly species - N. intermedia and $N$. neivai - are highly localized, with a very restricted distribution, and are primarily found in a small number of municipalities in the southern-most and south-eastern coastal regions of the state, where there is a high incidence of ACL (Figures 2 and 3). Other sand fly species N. whitmani, M. migonei, P. fischeri and P. pessoai - are much more broadly distributed and found in a relatively large number of municipalities, throughout the state of São Paulo, with variable levels of ACL (Figures 4, 5, 6 and 7 , and Table 1). Although the latter four sand fly species are broadly distributed, there is still a tendency for each species to be located in distinct regions of the state of São Paulo, with different levels of ACL, as described in further detail in the discussion below. For example, $P$. fischeri is widely distributed throughout the southernmost and south-eastern regions, where high levels of ACL are reported (Figure 6), while P. pessoai exhibits a converse pattern, primarily being widely distributed in the western region of the state of São Paulo, where there are low to medium levels of ACL (Figure 7). Although 


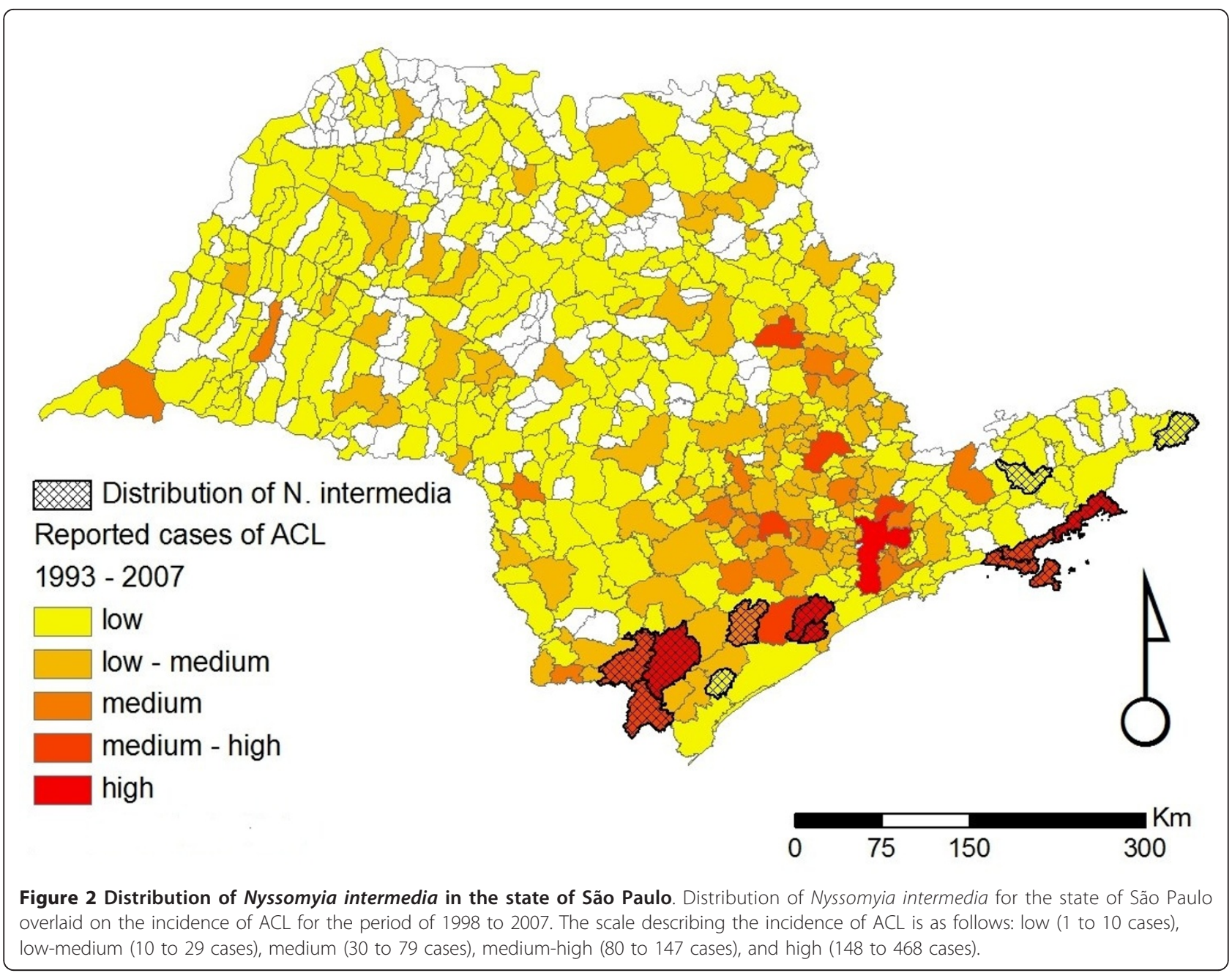

each sand fly species exhibits a unique distribution, there is considerable overlap in the distributions of the sand fly species, and in many municipalities $(72 / 183$, or $39.3 \%$ of those municipalities where at least one sand fly vector is found) more than one sand fly species has been reported. This pattern is particularly apparent for those municipalities reporting high levels of ACL, where 3 or more sand fly species often occur in apparent sympatry. For example, in the southern-most focus of high ACL incidence, four sand fly species - N. intermedia, $N$. neivai, $P$. fischeri and M. migonei - have been reported. Similarly, in the municipality comprising the city of São Paulo 5 of the 6 incriminated or suspected sand fly vectors of ACL are found: N. neivai, N. whitmani, P. fischeri, P. pessoai and $M$. migonei. However, the apparently high number of cases in this latter area probably results from mis-characterization of people seeking the higher quality medical services available in São Paulo city, the capital of the state, rather than the presence of appreciable levels of ACL transmission in this region.

\section{Discussion}

Many vector-borne infectious diseases involve the same aetiological agent, but different vectors and hosts in different regions [22]. In the state of São Paulo, at least six different sand fly species are suspected or incriminated vectors of Leishmania braziliensis, the main aetiological agent of ACL. Here, we presented the distribution of $N$. intermedia, N. neivai, N. whitmani, P. fischeri, P. pessoai, and M. migonei, over a period of 65 years, and compared their distributions to the distribution of ACL between the years 1993 to 1995 and 1998 to 2007.

Our database and the figures generated from it have some limitations, reflecting the quality of the original data sources that were used during its compilation. The data presented here will show the areas where the most of the entomological work has been done. Those areas of the state of São Paulo that do not have any records, do not necessarily indicate that there are no sand flies or ACL transmission, only that no species identifications have been published from those areas, or that disease 


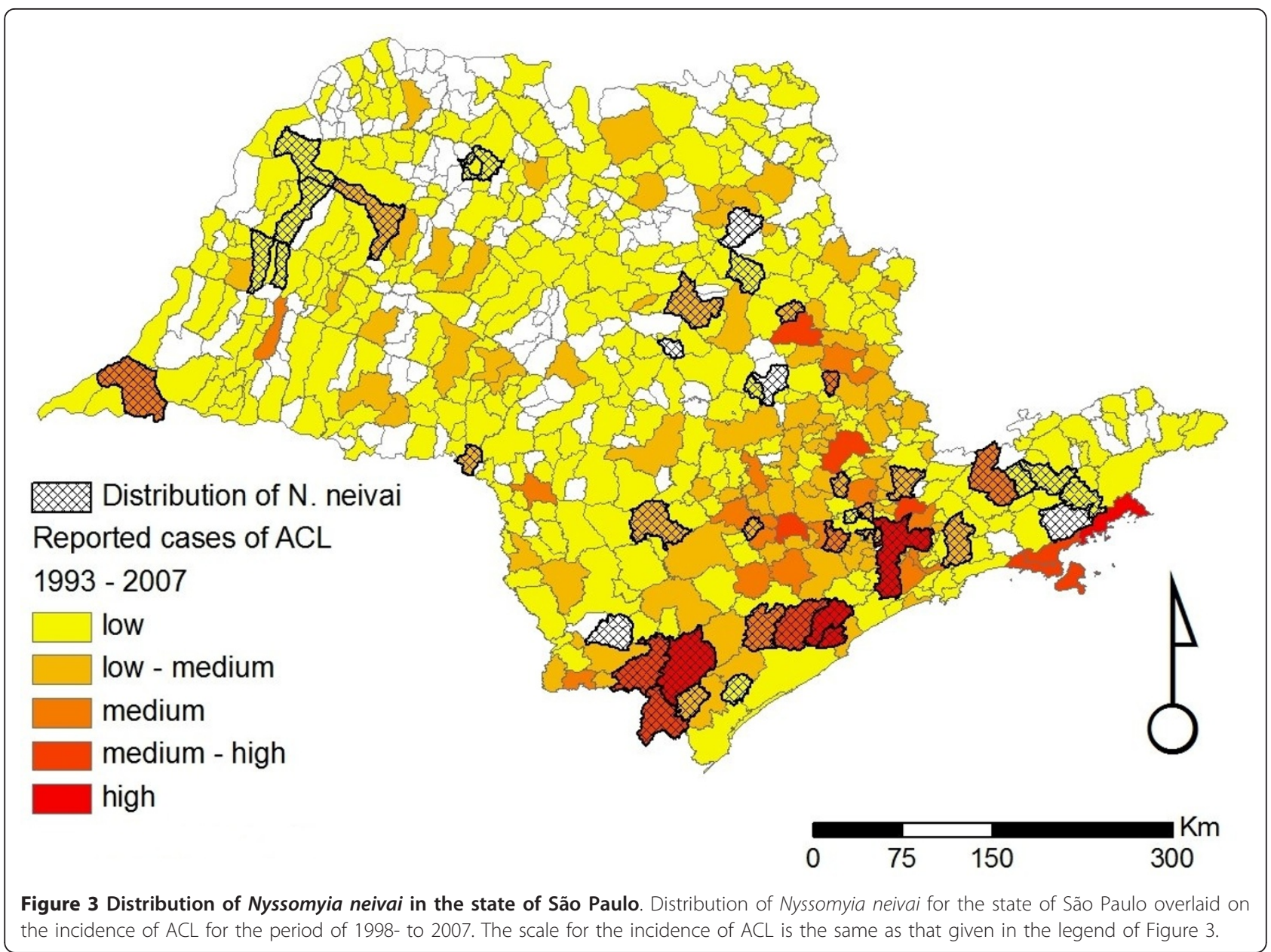

notification might have been made in other cities. Caution is also needed as some data might be inaccurate because of out-of-date and/or incorrect species identification. For example, 154 records were found for the distribution for $N$. intermedia sensu lato, which cannot be checked to confirm whether it is $N$. intermedia sensu strictu or $N$. neivai (see below). Consequently, these records were excluded from our analysis. Of these excluded records, $77.9 \%$ were from municipalities in the Atlantic and Eastern Plateau, where N. intermedia s. s. has not otherwise been reported (Figure 2), suggesting that these records may represent $N$. neivai and that the latter is the most widespread vector species in these areas. The remaining excluded records were from (i) apparently sympatric areas, such as the Ribeira and Paraíba rivers valleys [8], where both species are probably present (17.6\% of the excluded records), and (ii) coastal regions ( $4.5 \%$ of the excluded records), where probably only $N$. intermedia s. s. is present, as there are no independent records of $N$. neivai in these areas. One further limitation of the present study is that we used point data to construct our database and to produce the distributional maps for each vector species, since information from the literature is generally insufficient to map species abundance (i.e. density versus absence/ presence).

Patterns of ACL transmission in the state of São Paulo have been changing due to human impact on the environment. Human factors contributing to altering epidemiological patterns and the re-emergence of vector-borne diseases include changes in land use which cause redistribution of synanthropic fauna [23], urbanization, migration and population mobility, and the construction of dams, pipelines and highways that affect the landscape $[23,24]$. Such factors have led to changing distributions of the sand fly vectors if ACL in the state of São Paulo over the last 100 years. Below is given the description of the distribution of the six incriminated or suspected vectors of ACL in the state of São Paulo.

$N$. intermedia was one of the first species described in the New World and also one of the first to be associated with ACL transmission in the southeast of Brazil. Today, it is known to be a complex of at least two species: $N$. intermedia s. s. and $N$. neivai $[7,8]$. In the state of 


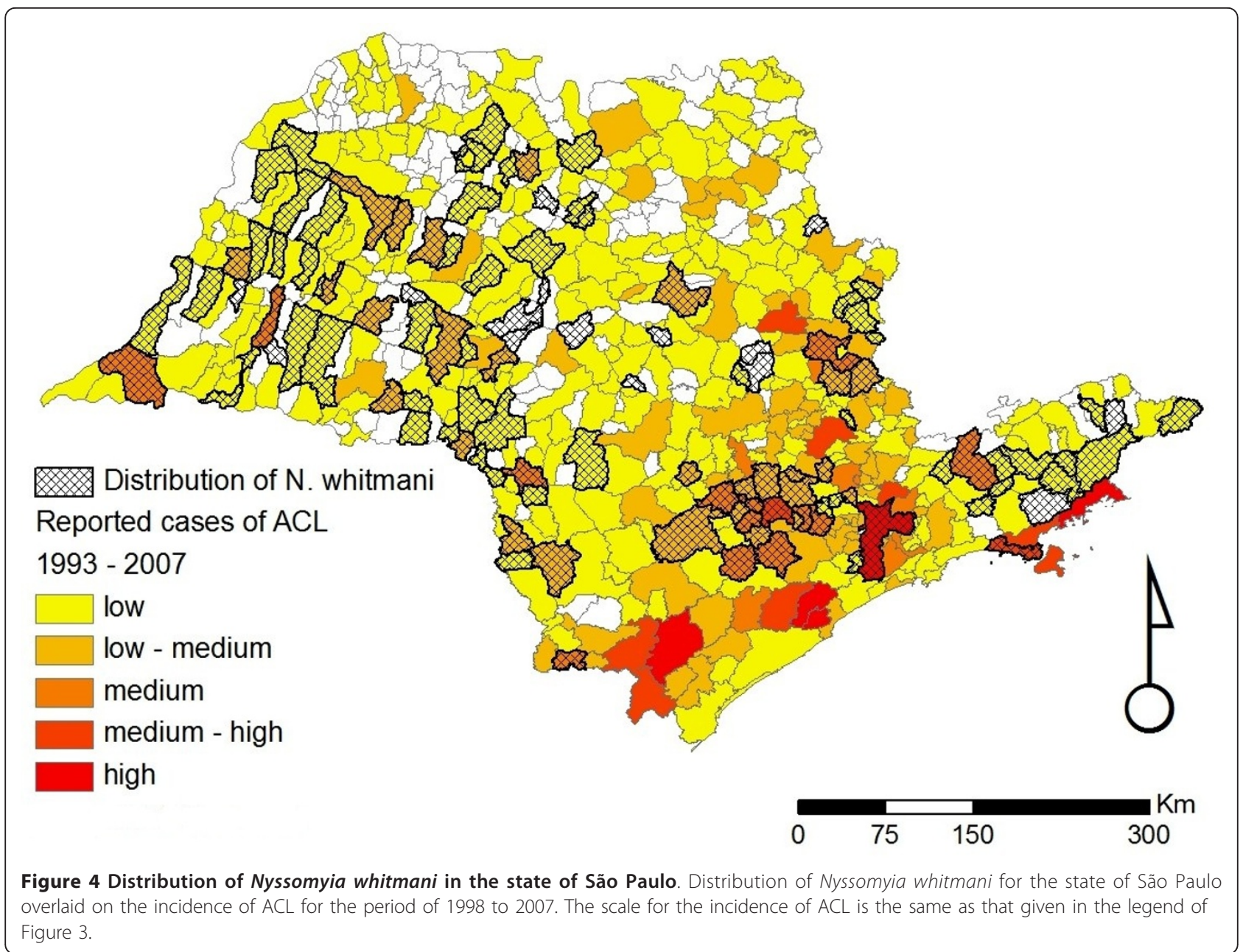

São Paulo, N. intermedia s. s. is more commonly associated with lowland coastal areas, with hot and wet climates (Figures 8 and 2), where ACL transmission has increased since 2002 [25], while N. neivai is found at higher altitudes, with dryer climates, characteristic of the Plateau area in the west of the state (Figures 8 and 3 ). Because of the widespread distribution in the Plateau areas, $N$. neivai might account for most of the records for $N$. intermedia made in the past (see above). However, the two species have been found in sympatry in both southern areas (the Ribeira river valley), where ACL incidence is the highest in the state [26], as well the eastern area of the state, where it is crossed by the Mogi-Guaçu and Paraíba rivers. The latter region showed the greatest increase in the incidence of ACL between 1979 and 1992, mainly along the Mogi-Guaçu river [1] (Figures 2 and 3). In the Ribeira valley region, $N$. neivai seems to be more likely than $N$. intermedia to overcome adverse conditions in open cultivated areas and adapt to anthropic changes to the environment [27]. Thus, deforestation and changes in land use could have led $N$. neivai to occupy new areas and replace existing species in the Plateau area as observed by Odorizzi \& Galati [28] and Casanova et al. [29,30]. Both species have been found naturally infected by L. braziliensis in other Brazilian states [31,32]; in the Plateau areas of São Paulo state, $N$. neivai (named $N$. intermedia at that time) was found naturally infected by unidentified flagellates $[33,34]$.

Nyssomyia whitmani was an important vector of $L$. (V.) braziliensis in São Paulo state in the first decades of the twentieth century due to its anthropophilic habit and its high density in endemic areas during the deforestation period of the Plateau (Figure 4), and the subsequent establishment of houses that are located in either the forest or adjacent cleared areas [6,35-37]. This species might coexist with $N$. intermedia s. 1 . (now $N$. neivai), but might be replaced by the latter in case of anthropic activities and deforestation [38,39]. Ecological niche modelling under different global climate change scenarios of ACL vectors in south-eastern Brazil suggested that only $N$. whitmani is likely to expand its distribution in 


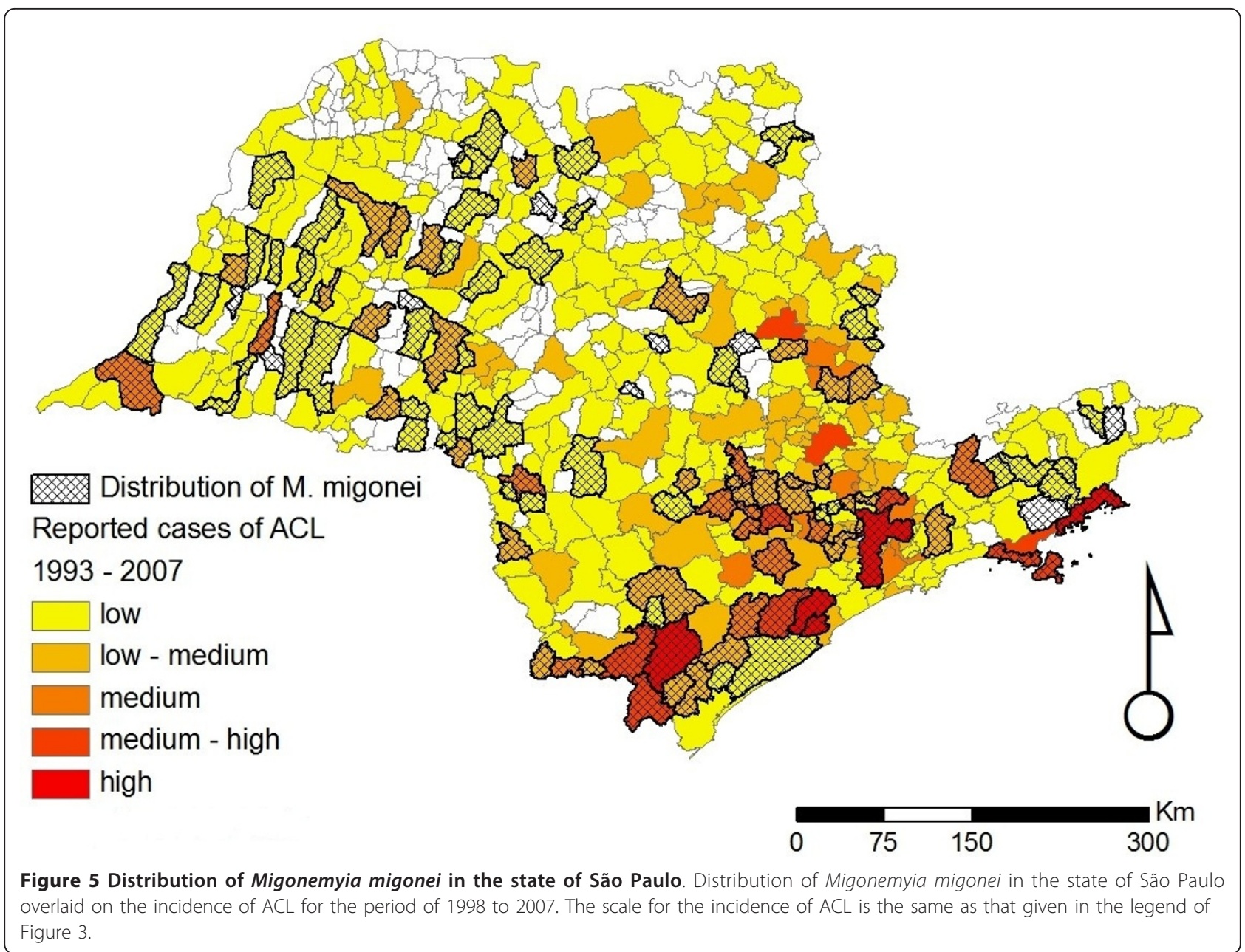

southern Brazil [18]. In this perspective, it is likely that this species might expand to the Ribeira river valley where the Atlantic forest is better preserved. This species was found naturally infected with $L$. $(V$.) braziliensis in other Brazilian states [40], and it was found infected by unidentified flagellates in the state of São Paulo [41].

Migonemyia migonei has been described as a sylvatic species that might be found at lower abundance in secondary forests [35]. This species is highly anthropophilic and may be found in animal shelters; through this adaptation to domiciliary/peridomiciliary environments, $M$. migonei can thus maintain enzootic transmission from the adjacent secondary forests [35]. Migonemyia migonei has a widespread distribution throughout the state (Figure 5), with records in areas of high transmission and in the Eastern Plateau, where high transmission occurred in the beginning of the twentieth century [1] This species has been found naturally infected by L. braziliensis in other states of Brazil [31,40] and by undetermined Leishmania sp. in the state of São Paulo by Pessôa \& Coutinho [41]. A correlation between the presence of this sand fly species and records of ACL cases was demonstrated by Camargo-Neves et al. [2], based on the records of sand flies captured during entomological surveillance between 1986 and 1995. Migonemyia migonei was found in areas where the incidence of ACL was higher, suggesting that this species might be important as a vector.

Pintomyia fischeri has never been found naturally infected by Leishmania, but it has been experimentally infected by this pathogen [41]. The anthropophily and high abundance of $P$. fischeri in transmission areas led Barretto \& Coutinho [42] to believe that this species might act as a secondary vector. This species has a widespread distribution throughout the state, along the coast and in the more preserved areas of the Atlantic Plateau (Figure 6). It has been found frequently inside houses, providing further evidence that this species could act as a vector [43]. Pintomyia fischeri has also been recorded in more humid forested areas, being dominant in forested areas of São Paulo city and surrounding municipalities [[36], Galati, unpublished data]. 


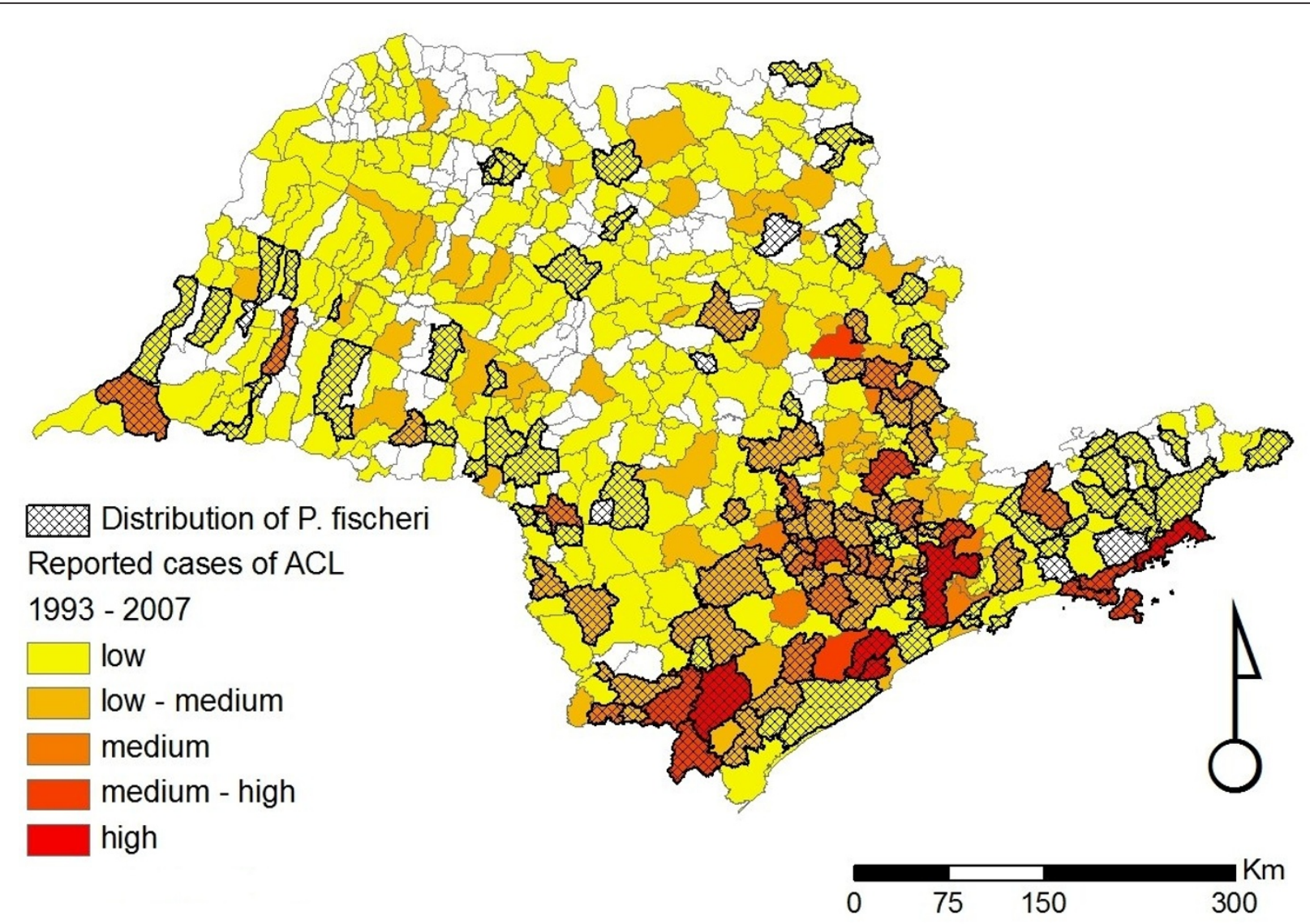

Figure 6 Distribution of Pintomyia fischeri in the state of São Paulo. Distribution of Pintomyia fischeri in the state of São Paulo overlaid on the incidence of $A C L$ for the period of 1998 to 2007. The scale for the incidence of $A C L$ is the same as that given in the legend of Figure 3.

It is noteworthy to mention that this species is not recorded along Tietê river course which is characterized by tropical climate with dry winter (Aw of the Koeppen climate classification system).

Pintomyia pessoai has been found in recently deforested areas and also occurs in human and domestic animal housing [35]. It was found naturally infected by unidentified flagellates $[34,41]$ suggesting its involvement in ACL transmission in southeastern Brazil [13]. Gomes \& Galati [44] suggested that $P$. pessoai could act as a secondary vector in the northwest-central part of São Paulo state due to its presence in primary forest. More recently, P. pessoai was the most abundant species collected in the northwestern region of the state [45]. This species is mostly found in the Plateau area, in patches of semi-deciduous tropical forest and the savannah-like (cerradão) vegetation, while it is rarely found in the hygrophilous, non-deciduous forest found along the coast (Figure 7).

\section{Conclusions}

The maps produced in this work provide basic data on the distribution of the six incriminated or suspected sand fly vectors of ACL in the state of São Paulo, and highlight the complex and geographically heterogeneous pattern of ACL transmission in the region, in which more than one species of sand fly is often implicated. The database reported here will be updated continuously, as new epidemiological information on ACL incidence and distributional records of sand flies are published. Further studies investigating vector feeding habits and natural infection rates are required to clarify the role of each of the six suspected sand fly vector species in different regions of the state of São Paulo. New tools to improve surveillance of cases of infection in humans and non-human animal reservoirs (wild and domestic), as well as vector monitoring, also need to be developed. Further entomological work is required in the large number of municipalities where ACL is present but sand fly vectors have not yet been identified. In the latter regard, the information provided by the descriptive distribution maps presented here will, in future, provide a starting point to generate more sophisticated predictive maps of vector occurrence and disease-risk based on statistical pattern-matching [46]. 


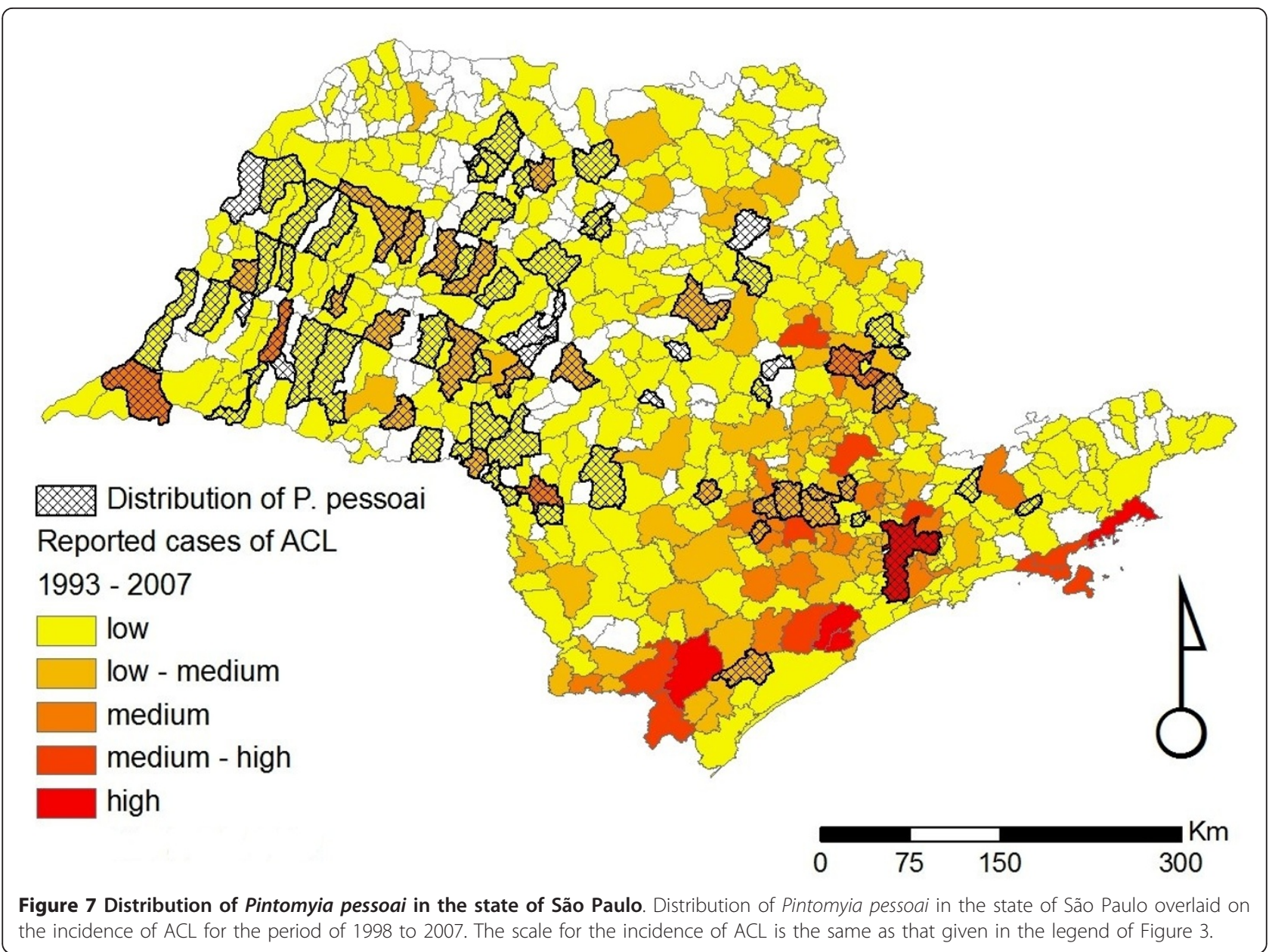

\section{Methods}

\section{Study area}

The São Paulo state, Brazil, has a total area of $248,209.426 \mathrm{~km}^{2}$, which is comprised of 645 municipalities, with a total population of approximately $39,827,570$ inhabitants [47]. The state of São Paulo is responsible for $33.9 \%$ of the gross domestic product (GDP) of Brazil [48].
São Paulo state is divided into five reliefs: Coastal Province, Atlantic Plateau, Peripheral Depression, Basaltic Cuestas and Eastern Plateau (Figure 8) [49]. Only 13.4\% of original vegetation remains; of these, the Atlantic forest and savannah-like ecosystem (cerradão) are the most important, and cover $11.4 \%$ and $1.2 \%$ of the state surface, respectively (Figure 8) [50].

Table 1 Number of records for the six incriminated or suspected sand fly vector species involved in ACL transmission, and the number of municipalities with records for $A C L$

\begin{tabular}{cccc}
\hline $\begin{array}{c}\text { Vector Species } \\
\text { municipalities }\end{array}$ & $\begin{array}{c}\text { Number of municipalities with notified } \\
\text { ACL cases }\end{array}$ & $\begin{array}{c}\text { Percentage of municipalities with both vector } \\
\text { and ACL }\end{array}$ & $100 \%$ \\
\hline $\begin{array}{c}\text { Nyssomyia intermedia } \\
\text { s.s. }\end{array}$ & 13 & 13 & $93 \%$ \\
\hline N. neivai & 42 & 39 & $85 \%$ \\
\hline N. whitmani & 113 & 96 & $90 \%$ \\
\hline Migonemyia migonei & 116 & 104 & $91 \%$ \\
\hline Pintomyia fischeri & 124 & 113 & $78 \%$ \\
\hline P. pessoai & 79 & 62 & \\
\hline
\end{tabular}

Number of records for the most important species involved in ACL transmission and number of municipalities with records for ACL. 


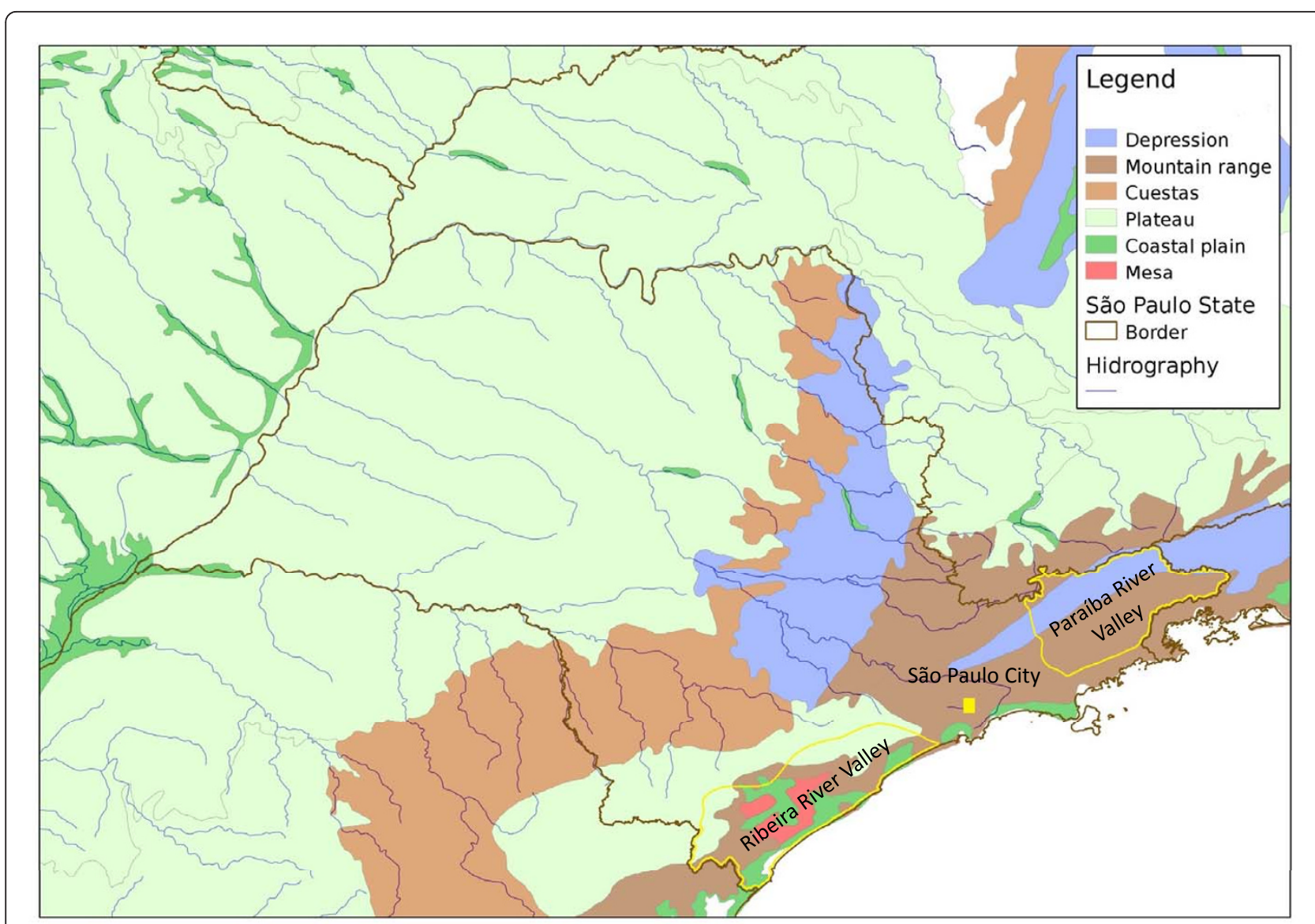

Figure 8 Topography of the state of São Paulo. Topography of the state of São Paulo including reliefs and hydrography.

\section{Database}

In order to understand and control the transmission of ACL, biological and epidemiological data have been collected by entomologists and health professionals throughout the different municipalities of the state of São Paulo for many decades. However, these data derive from disparate sources, employing diverse collection methods, and have not previously been assembled into a single resource for analysing and understanding patterns of vector distribution and ACL incidence. In the present work, we collated and systematically organized into a single database the disparate data already available on the distribution of sand flies in the state of São Paulo. The distribution of sand flies (Nyssomyia intermedia, N. neivai, N. whitmani, Pintomyia fischeri, P. pessoai and Migonemyia migonei) was based on: (i) examination of material deposited at reference entomological collections (Museu de Zoologia da Universidade de São Paulo, and Departamento de Epidemiologia/Faculdade de Saúde Pública/Universidade de São Paulo), (ii) scientific publications (papers, reports, theses), (iii) the Superintendência de Controle de Endemias/SES database [51], and (iv) personal communication with Dr. Claudio Casanova (SUCEN). In some instances, the names and boundaries of the municipalities have changed from those used in the original publications. Where we have been unable to find the current identity of these old municipalities, we have excluded the data from the database.

The nomenclature of the sand fly species follows Galati 2003 [52].

The data on the incidence of ACL in the state of São Paulo were obtained from, and are available at, the National Database on Reportable Diseases/Epidemiological Surveillance Centre SINAN/CVE website [21]. We used all the data from notified ACL cases from 1998-2007.

All the data were compiled in a Microsoft ACCESS $2007^{\mathrm{rm}}$ database, so that it was compatible with the software ArcGIS version 9.3 (Environmental Systems Research Institute, Inc., Redlands, California, United States), used in geoprocessing. The ACCESS $2007^{\mathrm{TM}}$ sand fly distribution database included the following categories: state, municipality, family, subtribe, genera, species and the references from which the data were 
obtained. This information was exported to the Databases Managing System (SGBD) POSTGRESQL. The POSTGRESQL software allows queries using SQL language to quantify and qualify the data. The queries were generated to visualize an event, such as distribution of a given species. The intervals describing the level of the incidence of ACL in Figures 2, 3, 4, 5, 6, 7 to distribute ACL data were: low (1 to 10$)$, low-medium (10 to 29 ), medium (30 to 79), medium-high (80 to 147), and high (148 to 4680). From the ARCGIS 9.3 package, the ARCMAP and ARCCATALOG applications were used with tools from the ARCTOOLBOX, specific for geoprocessing. The database produced in this project will be made available on request from PHFS.

\section{Geodatabase}

In order to produce the geodatabase, the Brazilian information database of the Laboratório de Sistemas de Informações Geográficas from Instituto Nacional de Pesquisas da Amazônia (SIGLAB/INPA) was used. These information is provided by the Instituto Brasileiro de Geografia e Estatística (IBGE) [48].

\section{Acknowledgements}

We are grateful to Dr. Claudio Casanova for sharing unpublished information on the distribution of sand fly species collected in São Paulo state. We also thank Ms. Sandra Cunha from SINAN for providing information on ACL cases, and Dr. Sylvain J. M. Desmoulière for kindly providing the topography map.

\section{Author details}

${ }^{1}$ Instituto Leônidas e Maria Deane, FIOCRUZ - Amazônia, Rua Terezina, 476, Adrianópolis, Manaus, Amazonas, Brazil. ${ }^{2}$ Universidade Estadual do Amazonas, Avenda Djalma Batista, 2470, Chapada, Manaus, Amazonas, Brazil. ${ }^{3}$ Instituto Nacional de Pesquisa da Amazônia, Avenida André Araújo, 2936, Aleixo, Manaus, Amazonas, Brazil. ${ }^{4} 50$ Rowntree Way, Saffron Walden, Essex, CB11 4DL, UK. ${ }^{5}$ Faculdade de Saúde Pública da Universidade de São Paulo, Departamento de Epidemiologia, Avenida Dr. Arnaldo, 755, Cerqueira César, São Paulo, São Paulo, Brazil.

\section{Authors' contributions}

PHFS conceived of the study, collected the data and drafted the manuscript. TRRS built the database. FORF elaborated the figures using GIS. LAB participated in the data analysis, helped to draft the manuscript, and revised the English. EABG participated in the data analysis and helped to draft the manuscript. All authors read and approved the final manuscript.

\section{Competing interests}

The authors declare that they have no competing interests.

Received: 10 September 2010 Accepted: 20 December 2010 Published: 20 December 2010

\section{References}

1. Tolezano JE: Ecoepidemiological Aspects of American cutaneous leishmaniasis in the state of São Paulo, Brazil. Mem Inst Oswaldo Cruz 1994, 83:427-434.

2. Camargo-Neves VLF, Gomes AC, Antunes JLF: Correlação da presença de espécies de flebotomíneos (Diptera: Psychodidae) com registros de casos de leishmaniose tegumentar americana no Estado de São Paulo, Brasil. Rev Soc Bras Med Trop 2002, 35:299-306.

3. Tolezano JE: Ecoepidemiologia da leishmaniose tegumentar americana (LTA). Perpetuação da LTA no Estado de São Paulo, região endêmica de colonização antiga. PhD thesis Universidade de São Paulo, Instituto de Ciências Biomédicas; 2000.

4. Marzochi MCA: As leishmanioses no Brasil. As leishmanioses tegumentares. J Bras Med 1992, 63:82-104.

5. Tolezano JE, Macoris AS, Dinis JMP: Modificação na epidemiologia da leishmaniose tegumentar no Vale da Ribeira, Estado de São Paulo. Rev Inst Adolfo Lutz 1980, 40:49-54.

6. Tolezano JE, Araújo MFL, Balanco JMF, Valentin AM, Barca ML: Leishmania sp. isolated from blood heart of Akodon sp. (Rodentia, Cricetidae) caught in Iguape City, São Paulo State, Brazil. Mem Inst Oswaldo Cruz 1988, 83:38.

7. Marcondes CB: A redescription of Lutzomyia (Nyssomyia) intermedia (Lutz \& Neiva, 1912), and resurrection of L. neivai (Pinto, 1926) (Diptera, Psychodidae, Phlebotominae). Mem Inst Oswaldo Cruz 1996, 91:457-462.

8. Andrade Filho JD, Galati EAB, Falcão AL: Nyssomyia intermedia (Lutz \& Neiva, 1912) and Nyssomyia neivai (Pinto, 1926) (Diptera: Psychodidae: Phlebotominae) geographical distribution and epidemiological importance. Mem Inst Oswaldo Cruz 2007, 102:481-487.

9. Yoshida ELA, Cuba Cuba CA, Pacheco RS, Cupolillo E, Tavares CC, Machado GMC, Momen H, Grimaldi G Junior: Description of Leishmania (Leishmania) forattinii sp. n. a new parasite infecting opossums asn rodents in Brazil. Mem Inst Oswaldo Cruz 1993, 88(3):397-406.

10. Medeiros AR, Silva WA Jr, Roselino AM: DNA sequencing confirms the involvement of Leishmania (L.) amazonensis in American tegumentary leishmaniasis in the state of São Paulo, Brazil. Clinics 2008, 63(4):451-456.

11. Gomes AC, Galati EAB, Classer CM: Nota sobre encontro de Phlebotominae (Diptera: Psychodidae) no litoral sul do Estado de São Paulo, Brasil. Rev Saúde Públ 1990, 24:319-20.

12. Gomes AC, Galati EAB: Aspectos ecológicos da leishmaniose tegumentar americana. 5. Estratificação da atividade espacial e estacional de Phlebotominae (Diptera, Psychodidae) em áreas da região do Vale do Ribeira, Estado de São Paulo, Brasil. Mem Inst Oswaldo Cruz 1987, 82(4):467-473.

13. Rangel $E F$, Lainson R: Transmissores de leishmaniose tegumentar americana. In Flebotomíneos do Brasil. Edited by: Rangel EF, Lainson R. Rio de Janeiro, Editora Fiocruz; 2003:291-310.

14. Gomes AC: Sand fly vectorial ecology in the State of São Paulo. Mem Inst Oswaldo Cruz 1994, 89:457-60.

15. Forattini OP: In Entomologia Médica. Psychodidae. Phlebotominae. Leishmanioses. Bartonelose. Volume 4. São Paulo, Edgar Blucher Editora Ltda; 1973.

16. Rinaldi L, Musella V, Biggeri A, Cringoli G: New insights into the application of geographical information systems and remote sensing in veterinary parasitology. Geospat Health 2006, 1:33-47.

17. Margonari C, Freitas CR, Ribeiro RC, Moura ACM, Timbó M, Gripp AH, Pessanha JE, Dias ES: Epidemiology of visceral leishmaniasis through spatial analysis, in Belo Horizonte municipality, state of Minas Gerais, Brazil. Mem Inst Oswaldo Cruz 2006, 101:31-38.

18. Peterson AT, Shaw J: Lutzomyia vectors for cutaneous leishmaniasis in Southern Brazil: ecological niche models, predicted geographic distributions, and climate change effects. Int J Parasitol 2003, 33:919-931.

19. Peterson AT, Pereira RS, Neves VFC: Using epidemiological survey data to infer geographic distributions of leishmaniasis vector species. Rev Soc Bras Med Trop 2004, 37:10-14.

20. Aparicio C, Bitencourt MD: Spacial modeling of cutaneous leishmaniasis risk zones. Rev Saúde Pública 2004, 38:511-516.

21. Sistema de Informação de Agravos de Notificação/Centro de Vigilância Epidemiológica. [http://www.cve.saude.sp.gov.br/htm/cve_dnc.htm]

22. Cromley EK, McLafferty SL: GIS and Public Health New York, The Guilford Press; 2002.

23. Cranston P: Biogeographic Patterns in the evolution of Diptera. In The Evolutionary Biology of Flies. Edited by: Yeates DK, Wiegmann B. New York, Columbia University Press; 2005:274-311.

24. Vasconcelos PFC, Travassos da Rosa APA, Rodrigues SG, Travassos da Rosa ES, Dégallier N, Travassos da Rosa JFS: Inadequate management of natural ecosystem in the Brazilian Amazon region results in the emergence and reemergence of arboviruses. Cad Saúde Pública 2001, 17:156-164.

25. Condino MLF, Galati EA, Holcman MM, Salum MRB, Silva DC, NovaesJúnior RA: American cutaneous leishmaniasis on the northern coastline of the State of São Paulo, 1993 to 2005. Rev Soc Bras Med Trop 2008, 41:635-641. 
26. Silva AF, Latorre MRDO, Galati EAB: Factors relating to occurrences of cutaneous leishmaniasis in the Ribeira Valley. Rev Soc Bras Med 2010, 43:46-51.

27. Galati EAB, Fonseca MB, Marassá AM, Bueno EFM: Dispersal and survival of Nyssomyia intermedia and Nyssomyia neivai (Diptera: Psychodidae: Phlebotominae) in a cutaneous leishmaniasis endemic area of the speleological province of the Ribeira Valley, state of São Paulo, Brazil. Mem Inst Oswaldo Cruz 2009, 104:1148-1158.

28. Odorizzi RMFN, Galati EAB: Flebotomíneos de várzea do rio Aguapeí, região noroeste do Estado de São Paulo, Brasil. Rev Saúde Pública 2007, 41:645-52.

29. Casanova C, Costa AIP, Natal D: Dispersal pattern of the sand fly Lutzomyia neivai (Diptera: Psychodidae) in a cutaneous leishmaniasis endemic rural area in Southeastern Brazil. Mem Inst Oswaldo Cruz 2005, 100:719-724.

30. Casanova C, Natal D, Santos FA: Survival, population size, and gonotrophic cycle duration of Nyssomyia neivai (Diptera: Psychodidae) at an endemic area of American cutaneous leishmaniasis in southeastern Brazil. J Med Entomol 2009, 46:42-50.

31. Pita-Pereira D, Alves CR, Souza MB, Brazil RP, Bertho AL, FigueiredoBarbosa A, Britto CC: Identification of naturally infected Lutzomyia intermedia and Lutzomyia migonei with Leishmania braziliensis in Rio de Janeiro (Brazil) revealed by PCR multiplex non-isotopic hybridization assay. Trans Roy Soc Trop Med Hyg 2005, 99:905-913.

32. Pita-Pereira D, Souza GD, Zwetsch A, Alves CR, Britto C, Rangel EF: First report of Lutzomyia (Nyssomyia) neivai (Diptera: Psychodidae: Phlebotominae) naturally infected by Leishmania (Viannia) braziliensis in a periurban area of south Brazil using a multiplex polymerase chain reaction assay. Am J Trop Med Hyg 2009, 80:593-595.

33. Forattini OP, Santos MR: Nota sobre a infecção natural de Phlebotomus intermedius Lutz \& Neiva, 1912, por forma leptomonas, em um foco ativo de leishmaniose tegumentar americana. Arq Hig S Publ S Paulo 1952, 17:171-174.

34. Forattini $O P$, Pattoli $D G B$, Rabello EX, Ferreira $A O$ : Infecção natural de flebotomíneos em foco enzoótico de leishmaniose tegumentar no Estado de São Paulo, Brasil. Rev Saúde Pública 1972, 6:431-433.

35. Barretto MP: Observações sobre a biologia, em condições naturais, dos flebótomos do Estado de São Paulo (Diptera, Psychodidae). PhD thesis Universidade de São Paulo, Faculdade de Medicina; 1943

36. Taniguchi HH, Tolezano JE, Correa FMA, Moraes RHP, Veiga RM, Marassa AM: Epidemiologia da leishmaniose americana no Estado de São Paulo, Brasil, 1. Composição da fauna flebotomínica o Município de São Roque, Região de Sorocaba. Rev Inst Adolfo Lutz 1991, 51:23-30.

37. Tolezano JE, Novelli MA, Taniguchi HH: Leishmaniose tegumentar no Estado de São Paulo. VI. Avaliação do comportamento antropofílico de flebotomíneos em áreas endêmicas. Mem Inst Oswaldo Cruz 1992, 87:219.

38. Forattini OP: Novas observações sobre a biologia de flebótomos em condições naturais (Diptera: Psychodidae). Arq Fac Hig Saúde Pública 1960, 25:209-215.

39. Condino MLF, Sampaio SMP, Henriques LF, Galati EAB, Wanderley DMV, Côrrea FMA: Leishmaniose tegumentar americana: flebotomíneos de área de transmissão no município de Teodoro Sampaio, região sudoeste do estado de São Paulo, Brasil. Rev Soc Bras Med Trop 1998, 31:355-360.

40. Queiroz RG, Vasconcelos IA, Vasconcelos AW, Pessoa FA, Sousa RN, David JR: Cutaneous leishmaniasis in Ceará state in northeastern Brazil: incrimination of Lutzomyia whitmani (Diptera: Psychodidae) as a vector of Leishmania braziliensis in Baturité municipality. Am J Trop Med Hyg 1994, 50:693-698.

41. Pêssoa SB, Coutinho JO: Infecção natural e experimental de flebótomos pela Leishmania braziliensis no Estado de São Paulo. Hospital 1941, 20:25-30.

42. Barretto MP, Coutinho JO: Contribuição ao conhecimento dos flebótomos de Sao Paulo, VI. Descrição de duas novas espécies (Diptera, Psychodidae). Papéis Avulsos Dept Zool São Paulo 1941, 1:223-226.

43. Gomes AC, Camargo-Neves VL: Estratégia e perspectivas de controle da leishmaniose tegumentar no Estado de São Paulo. Rev Soc Bras Med Trop 1998, 31:553-558.

44. Gomes AC, Galati EAB: Aspectos ecológicos da leishmaniose tegumentar americana: 7-Capacidade vetorial flebotomínea em ambiente florestal primário do Sistema da Serra do Mar, região do Vale do Ribeira, Estado de São Paulo, Brasil. Rev Saúde Pública 1989, 23:136-142.
45. Alessi CÁC, Galati EAB, Alves JR, Corbett CEP: American cutaneous leishmaniasis in the Pontal of Paranapanema - SP, Brazil: ecological and entomological aspects. Rev Inst Med trop S Paulo 2009, 51:277-282.

46. Randolph SE: Ticks and tick-borne disease systems in space and from space. Adv Parasitol 2000, 47:217-243.

47. Instituto Brasileiro de Geografia e Estatística. [http://www.ibge.gov.br/ cidadesat/topwindow.htm?1].

48. Instituto Brasileiro de Geografia e Estatística. [http://www.ibge.gov.br/ home/presidencia/noticias/noticia_visualiza.php?

id_noticia=1756\&id_pagina=1].

49. Almeida FFM: Fundamentos Geológicos do Relevo Paulista. PhD thesis Universidade de São Paulo, Instituto de Geografia; 1964.

50. Estado de São Paulo/Secretaria do Meio Ambiente/Coordenadoria de Informações Técnicas, Documentação e Pesquisa Ambiental; Instituto Florestal: Inventário Florestal do Estado de São Paulo 1993.

51. Camargo-Neves VLF: Características da Transmissão da Leishmaniose Tegumentar Americana no Estado de São Paulo, Brasil. Masters thesis Faculdade de Saúde Pública da Universidade de São Paulo; 1999.

52. Galati EAB: Morfologia e Taxonomia: Classificação de Phlebotominae. In Flebotomíneos do Brasil. Edited by: Rangel EF, Lainson R. Rio de Janeiro, Editora Fiocruz; 2003:3-51.

doi:10.1186/1756-3305-3-121

Cite this article as: Shimabukuro et al.: Geographical distribution of American cutaneous leishmaniasis and its phlebotomine vectors (Diptera: Psychodidae) in the state of São Paulo, Brazil. Parasites \& Vectors 2010 3:121.

\section{Submit your next manuscript to BioMed Central and take full advantage of:}

- Convenient online submission

- Thorough peer review

- No space constraints or color figure charges

- Immediate publication on acceptance

- Inclusion in PubMed, CAS, Scopus and Google Scholar

- Research which is freely available for redistribution

Submit your manuscript at www.biomedcentral.com/submit
C Biomed Central 